\title{
MOBILE ASSISTED LANGUAGE LEARNING FOR DEVELOPING CRITICAL READING SKILLS OF EFL UNIVERSITY STUDENTS
}

\author{
Zainab Hasan Muhammad Saleh \\ Demonstrator at Curriculum and Instruction Dept. (TEFL), Faculty of \\ Education, Suez University, Suez, Egypt.
}

Dr.Samah Zakareya Ahmad

Associate Professor of Curriculum \& Instruction (TEFL), Instruction (TEFL), Faculty of Education, Suez University
Dr.Samah Mohammed Fahim

Associate Professor of Curriculum \&

Faculty of Education, Suez University

\begin{abstract}
The current study has investigated the effect of a mobile-assisted language learning (MALL) program on EFL students' critical reading skills. The study followed a quasi-experimental one-group design. The study participants were 40 third-year EFL majors at the Faculty of Education, Suez University during the second semester of 2017/2018. A pre/posttest was prepared by the researcher to measure participants' critical reading skills. At the beginning of the experiment, the participants were pretested. After the administration of the experiment for three months, the participants were post-tested. A paired samples t-test revealed that a statistically significant difference existed between the mean score of the pretest and that of the posttest $(t=14.807, p<0.05)$ in favor of the posttest. This result indicated that the treatment program had a good impact on developing EFL critical reading skills of the study participants. It was concluded that mobile learning had a significant effect on third-year EFL majors' critical reading skills. The study, therefore, recommends mobile learning to be incorporated in EFL college reading courses.
\end{abstract}

KEYWORDS - Mobile-assisted language learning (MALL), critical reading skills, higher education. 


\section{SKILLS OF EFL UNIVERSITY STUDENTS}

\section{تعلم اللغة باستخدام الهاتف النقال لتتمية مهارات القزاعة الناقدة لاى طلاب اللغة الإنجليزية كلغة أجنبية مالية مانية \\ الملخص العربي}

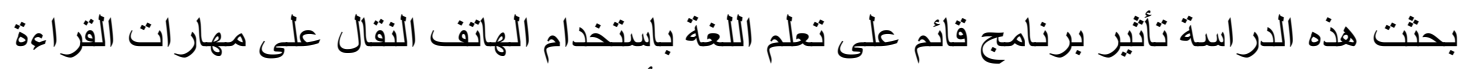

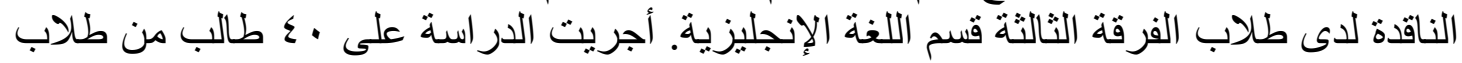

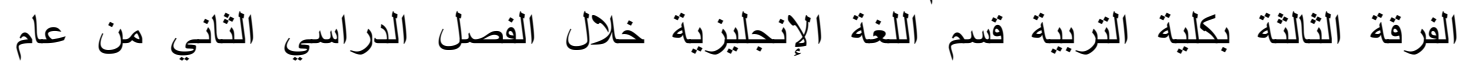

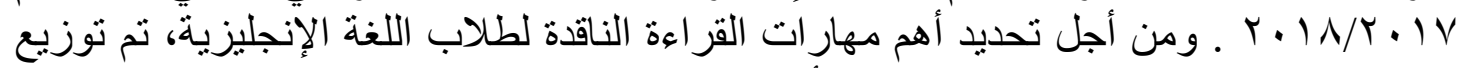

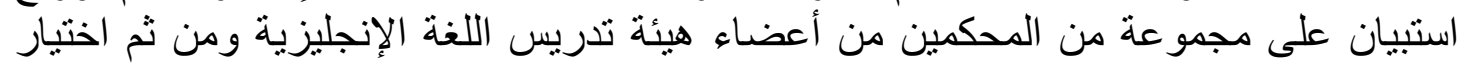

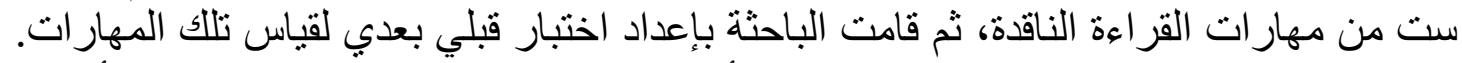

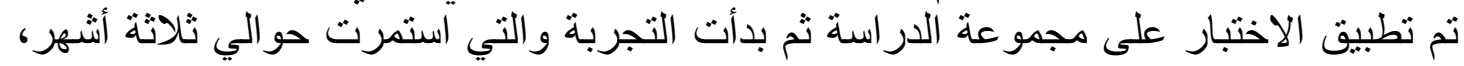

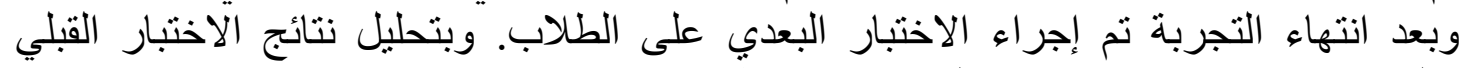
والبعدي باستخدام اختبار (ت) لعينتين منرابطتين Paired Sample T-Test تبين وجين وجود

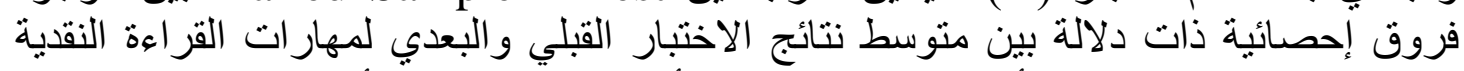

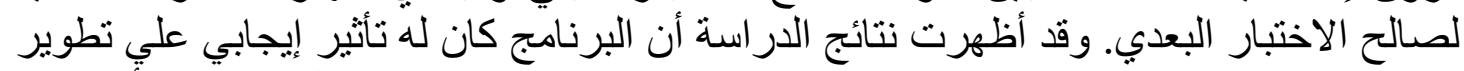

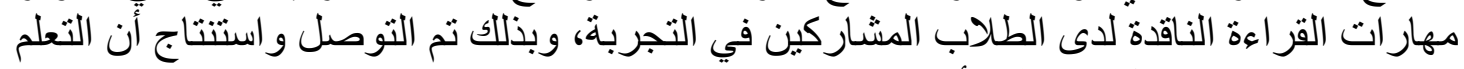

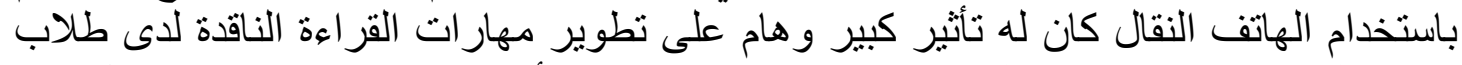

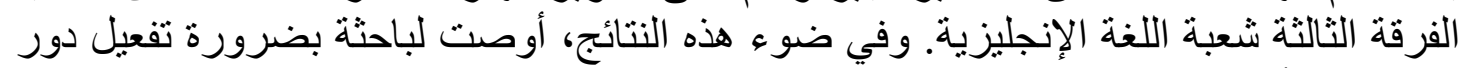

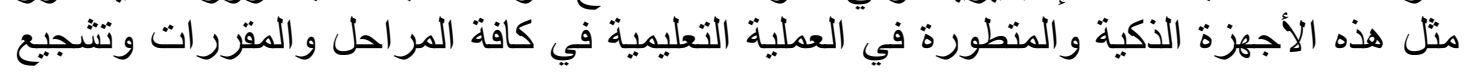

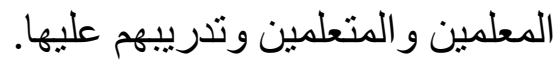




\section{INTRODUCTION}

\subsection{Background of the Study}

With the change of time and technology in the $21^{\text {st }}$ century, the teaching and learning practices are also changed. New portable electronic devices take place of old text books (Singh-Bhullar, 2014). Mobile phones as a new addition to information and communication technologies have created new ways to help learners in the process of foreign language learning, especially English language learning (Alemi, Reza, \& Anani, 2012). Mobile assisted language learning (MALL) is one approach that encompasses that opportunity with the multifunctional applications that students can access through their smartphones. The concept of mobile entertains the fact of knowledge availability "anywhere and anytime" (Geddes, 2004, p. 214), which suggests that the future will witness multiple changes in the educational system in general, specifically in its mobile format (Mekhzoumi, Hilmi, \& Krishnasamy, 2018). There is, however, a gloomy side to this information revolution and knowledge availability with one touch and a free open access to means of knowledge production. With the emergence of social media as the primary source of information in the $21^{\mathrm{St}}$ century, this gives a chance to amateurs to misuse and sometimes abuse these means. People become more vulnerable to believing fake news. Aside from the problem it poses in public as misleading readers, false news has also been a concern in education, affecting the quality of academic outputs that are written by students (Castro, 2019). In such a data-saturated world, the fine line between information and misinformation is getting alarmingly blurry (Kharbach, 2018). In this respect, in order to use knowledge effectively and productively, students should not only understand and interpret it correctly but also question its validity, efficiency and necessity and this is where critical reading skills comes into the picture.

The function and quality of reading activity nowadays become a critical issue which necessitate the acquisition and development of critical reading skills. This urges teachers and educators to raise their students' critical awareness to this informational dilemma. The need for preparing students with critical powers to cope with, direct, and even lead this change is remarkably increasing. It is important to ensure that they are equipped with the required skills, as Duncan (2006) calls them "essential survival skills for the new millennium", to help the students to navigate and browse the web in a safe and productive way. Students should be able to identify the author's ideas, compare them with others on the same 
topic, criticize and evaluate the content they find online (Karabay, Kusdemir \& Isik, 2015).

Surveying the literature of recent studies tackling the problem of critical reading skills for Egyptian students showed that many of them suffer from weaknesses in critical reading in the primary stage (e.g., Abdel Mageed, 2017; Al-Sayed, 2010; Bedeer, 2017), preparatory stage (Badawy, 2018; El-Mistikawy, 2016), secondary stage (Abu Zeid, 2017; Bahagat, 2015; El-Maleh, 2006), as well as at the college level (Ahmed, 2012; Barakat, 2018; Ellozy \& Mostafa, 2010; El-Sakka, 2011; Gharib, 2012; Makhyoun, 2008). As a demonstrator in the curriculum and instruction department at Faculty of Education, Suez University, the researcher noticed that while reading, EFL students focus mostly on the first two levels in Bloom's Taxonomy of thinking processes. That is knowledge/remembering and comprehension/understanding. They were able to create and respond to questions on these levels more effectively than on the higher-order thinking ones; application, analysis, synthesis/creation, and evaluation.

\subsection{PROBLEM STATEMENT}

Based on the researcher's experience, a pilot study administered on 20 third-year EFL students at Faculty of Education, Suez University. The test consisted of 20 questions to measure some common critical reading skills (see Table $1 \&$ Table 2) and the findings of the previous studies, the problem of this study was stated as there were some weaknesses in the critical reading skills of third year EFL students at Faculty of Education, Suez University. Therefore, a mobile-assisted language-learning program was proposed as a means of developing critical reading skills for those students.

Table 1: Mean Scores of Critical Reading Skills Pilot Test

\begin{tabular}{lccc}
\hline Skills & Allotted Mark & Mean & Percentage \\
\hline Identifying the Purpose & 3 & .95 & $31.7 \%$ \\
\hline Evaluating Relevance & 3 & 1.20 & $40 \%$ \\
\hline $\begin{array}{l}\text { Anticipating Intended } \\
\text { Meanings }\end{array}$ & 3 & 1.20 & $40 \%$ \\
\hline $\begin{array}{l}\text { Differentiating Facts \& } \\
\text { Opinions }\end{array}$ & 4 & 2.60 & $65 \%$ \\
\hline Drawing Inference & 4 & $2.3 \cdot$ & $57.5 \%$ \\
\hline Making Judgments & 3 & .70 & $23.3 \%$ \\
\hline Total & 20 & 8.95 & $44.75 \%$ \\
\hline
\end{tabular}


Zainab Hasan Muhammad

Table 2: Total Scores of Critical Reading Skills Pilot Test

\begin{tabular}{cccccccc} 
Total & N & Mean & Median & Skewness & Kurtosis & Minimum & Maximum \\
\cline { 2 - 7 } & 20 & 8.95 & 9 & 0.30 & -0.317 & 6 & 13
\end{tabular}

\subsection{QUESTIONS OF THE STUDY}

The present study attempted to find out answers to the following main question:

"What is the effect of a mobile assisted language learning program on the critical reading skills of EFL students?", and to the following subquestions:

1. What are the critical reading skills necessary for EFL students?

2. What are the components of a mobile assisted language-learning program for improving the critical reading skills of EFL major students?

3 . What is the impact of the devised program on the critical reading skills of EFL major students?

\subsection{HYPOTHESIS OF THE STUDY}

To investigate the above questions of this study the following hypothesis was formulated:

There would be no statistically significant difference in the participants' mean scores between the pretest and the posttest of critical reading skills.

\subsection{AIMS OF THE STUDY}

This study aimed to:

1. identify the critical reading skills that EFL students need to improve,

2. identify some of the mobile applications most suitable for the development of the critical reading skills of EFL students,

3. design a mobile assisted language-learning program to develop the critical reading skills of EFL major students, and

4. study the effect of the program on the development of the critical reading skills of third-year EFL students at Faculty of Education, Suez University.

\section{LITERATURE REVIEW}

\subsection{MOBILE ASSISTED LANGUAGE LEARNING}

Without a doubt, technology plays a significant role in setting learning free from the constraints of time and place. Under the umbrellas of mobile learning and language learning, MALL has appeared as a field of 
study since the 80s (Trinder, 2005) which involves that opportunity. MALL finds its promising, new spot on the surface of emerging trends in education (Al-Zahrani, 2015). O'Malley et al. (2005, p. 6) define MALL as "any sort of learning that happens when the learner is not in a fixed, predetermined location, or learning that happens when the learner takes advantage of the learning opportunities offered by mobile technologies." In their study in 2013, Rodríguez-Arancón, Arús, and Calle define MALL as a teaching and learning methodology that uses mobile phones or other handheld devices with some form of wireless connectivity, such as phones, PDAs and tablets, among others. Valarmathi (2011) states that the term MALL is a subset of both mobile learning (M-Learning) and computer assisted language learning (CALL). MALL involves using a mobile device for the purpose of enhancing language skills in reading, writing, speaking and/or listening. It wins an advantage over CALL since it extends into daily activities. Accordingly, it provides applicable solutions to progressively move from traditional face-to-face learning lessons to mobile learning ones using hand-held devices (Al-Zahrani, 2015).

\subsubsection{HISTORY OF MALL}

All through the history of educational technology, there have been trends tackling size and capabilities of innovative technologies that support teaching in the classroom (Al-Zahrani, 2015). The invention of smart phones, mobile phones, iPods, tablet PCs, hand-held computer based devices, PDAs, and MP3 players gave rise to Mobile-Assisted Language Learning (AbuSa'aleek, 2014). Reviewing the history of MALL, a research by Twarog and Pereszlényi-Pintér in the 80s marks the emergence of MALL which looked at telephone assisted language study. They used telephones to provide distant language learners with assistance and feedback (Twarog \& Preszlenyi Pinter, 1988). In the mid-1990s, one of the first published trends addressing MALL was a Canadian report by Callan (1994) which investigated the effect of word processing features with PDAs, compared to handwritten texts, to improve the English writing skills (Burston, 2013).

Apparently, over the past two decades from the beginning of the new millennium to the recent time, a publication of large amount of research remarkably existed which examined various mobile devices used in environments both inside and outside of formal language learning. There have been trials of MALL applications and the uses of multimedia on PDAs and iPods since 2001 (e.g., Belanger, 2005; Garcia Cabrere, 2002; 
Kukulska-Hulme, 2005). What could be observed from these trials is that the focus has mostly been on delivering basic features such as vocabulary learning and quiz drills in text format over mobile phones. Additionally, there was also an effort by Kiernan and Aizawa (2004) to look at the use of mobile devices on task based learning. They believed that task based learning is the best way to enhance the acquisition of language.

Moreover, Thornton and Houser (2005) conducted several pioneering projects involving the use of mobile devices particularly mobile phones which one of them focused on the teaching of the English language, specifically on vocabulary acquisition. Their findings are similar to those found by Levy and Kennedy (2005) who studied their Italian learners. They sent vocabulary words and idioms, definitions and example sentences via SMS. Another study that studies vocabulary learning was conducted by Chen and Chung (2008).

Other than that, there were also several attempts to use specific functions of mobile devices in language teaching and learning settings. Rivers (2009), for example, required Japanese learners of English to scan Quick Response $(\mathrm{QR})$ codes that were posted around the university in order to accomplish some information exchange tasks. QR codes are graphics scanned by mobile devices that automatically link to online information. In another study, Sandberg, Maris and de Geus (2011) provided young Dutch learners with mobile phones equipped with GPS capabilities in order to help them learn English vocabulary. Gromik (2012) required Japanese learners to use the video recording function of their mobile phones to produce short English monologues.

In December 2011 in Paris at the United Nations Educational, Scientific and Cultural Organization (UNESCO) headquarters, a number of experts from all over the world participated in a meeting to discuss the prevalence of MALL. This expert meeting was a cornerstone, indicating that m-learning is no longer a buzz word, but a concrete opportunity to reach the UNESCO goal of Education for All. (Ferreira, Klein, Freitas, \& Schlemmer, 2015).

Thus, such small devices as mobile ones are capable of doing as much as, and sometimes more than, larger desktop machines. These features have paved the way for the development of mobile language learning tools, approaches and integration in education starting from recent history to the unlimited opportunities that could take place in the future (AlZahrani, 2015). 


\subsubsection{ADVANTAGES OF MALL}

As Al-Zahrani (2015) states, the ever-growing and quickly changing pace of technology imposes the need for integrating new innovative technologies into education such as mobile learning technologies. In both K-12 and higher education domains, future generations, recently known by Prensky (2001) as digital natives, are more likely to own and be closely attached to mobile technologies more than ever. On the same trend, the UNESCO, in their guidelines in 2013, outlines a set of unique benefits of mobile learning that can be leveraged to advance progress towards Education for All. These benefits are: 1) expanding the reach and equity of education, 2) facilitating personalized learning, 3) providing immediate feedback and assessment, 4) enabling anytime, anywhere learning, 5) ensuring the productive use of time spent in classrooms, 6) building new communities of learners, 7) supporting situated learning, 8) enhancing seamless learning, 9) bridging formal and informal learning, 10) minimizing educational disruption in conflict and disaster areas, 11) assisting learners with disabilities, and 12) improving communication and administration. While mobile technology is not and never will be an educational solution for all challenges and difficulties, it is a powerful and often overlooked tool that can facilitate and support education in general and language learning in particular with many potentials that weren't possible earlier.

\subsection{CRITICAL READING}

Reading in general and critical reading in particular are considered among the most significant language skills (El-Maleh, 2006). As Abdel Halim (2011) indicates, our world is getting more complicated to understand, therefore helping students how to process information has become more critical than definite facts. The recent situation of web pages written in dozens of languages and instant messaging across the planet between people of various ethnic and cultural backgrounds impels higher education institutions to develop critical reading to stimulate global-level thinking (Abdel Halim, 2011) and to cope with the increase of knowledge and information which requires a critical reader not a naïve one (Alqatanani, 2017).

Wide-ranging definitions have been given to critical reading. Kurland (2002) defines critical reading as " a technique for discovering information and ideas within a text" (p. 1). McDonald (2004) considers critical reading as an alternative way of reading that goes beyond typical 


\section{Zainab Hasan Muhammad}

approaches of reading. Collins (2018) assumes that critical reading implies making judgments about how a text is argued. Similarly, Wray and Wallace (2011) believe that critical reading is rarely about questioning the facts, it is about how the text works, how it is argued and how it reaches its conclusions (Collins, 2018). Arıc1 (2012) defines critical reading as ideal reading. He claims that critical reading is being in a communicational interaction with the text and the ability to comment and evaluate the text. An individual's ability to keep what he has read in his mind for a long time can only be possible with critical reading (Akın, Koray, \& Tavukçu, 2015). In their study on critical reading, Khodary and AbdAllah (2014) define it as a technique for evaluating what is read.

As for critical readers, as asserted by Rivers (2001) and Wolters, Pintrich and Karabenick (2005), critical readers have been identified as having the ability to easily switch with the most suitable reading skills, even mainly difficult ones, as demanded by the situation (Albeckay, 2014). According to Aş1lıoğlu (2008), a reader who is not critical cannot exceed the level of perception in cognitive processes whereas a critical reader can acquire competencies at levels of analysis, synthesis and evaluation (Akın, Koray, \& Tavukçu, 2015). Rog (2012) defines critical readers as those who read beyond what the author states to how and why the author states it, questioning the attitudes, values, and beliefs that lie beneath the surface of the writing. They interpret new facts against their background knowledge and bring a complete range of their thinking and feeling into the reading act (Cusipag et al., 2006) postponing judgment until they have considered all the material (Roe \& Smith, 2011).

Critical reading skills in English Language are numerous. McClain (1985) points out that critical reading skills include reading material with an attentive and questioning mind, comparing and contrasting what has been read, considering the author's views and being aware of other viewpoints, detecting propaganda techniques, identifying relevant and irrelevant information and differentiating fact from opinion. Thistlethwaite (1992) reveals that critical reading skills are the writer qualification as an authority, the writer's bias and objectivity, the writer's purpose and tone, the up-to- datedness validity of the material, the writer's use of reasoning and support and the reader's own objectivity and biases. Critical reading proficiency are described by Carrigus (2002) at two levels of basic critical reading skills and high-level critical reading skills. The former focuses on paragraph analyzing while the latter on making inference and evaluating. Basic reading skills involve the ability to find the main idea of paragraphs, multi-paragraph units and articles, identify idea patterns of organization ' distinguish topical organization from organization by idea, and recognize transitions that signal 


\section{SKILLS OF EFL UNIVERSITY STUDENTS}

relationships among pattern elements and supporting details. High-level critical reading skills require students to draw inference and state implied main idea, synthesize two or more sentences to formulate divided main ideas, distinguish fact and opinion' evaluate evidence, explain figurative language (e.g. analogy), identify basic logical fallacies and emotional appeals. As for Khodary and AbdAllah (2014), critical reading skills entail the ability to identify the main idea, find the evidence the text employs, show author's point of view, guess the meaning of words in context, guess the author's intended meaning identify cause and effect relationships, recognize bias، draw conclusions, identify the audience, make inferences and recognize the tone. Based on the above views, critical reading skills revolve on three main skills: analyzing, synthesizing, and evaluating.

Critical reading is regarded as a very important life and learning skill (Nitsu, 2004). This may be due to many reasons. The nature of reading is rapidly changing as new technologies emerge (diSessa, 2000). Therefore, important is the ability to find the needed information among the vast amount of information available on the Internet, the ability to integrate information coming from multiple sources, and the ability to effectively use this information to solve problems (Leu \& Kinzer, 2000). As Varga (2011) indicates, students need to develop not only skills how to find the necessary and valid pieces of information but also the skills to deal with them. Moreover, EFL students at the college level usually get surprised at the differences between high school and college reading requirements. Instead of reading a few pages in their English textbook each week, college students are required to read a variety of materials outside of the class session: textbooks, primary documents, newspapers, magazines, academic journals, or online materials. Therefore, college students are expected to analyze, synthesize, and evaluate materials they read; they are required to read critically (Ahmed, 2012). Consequently, critical reading skills could open real possibilities in students' future working and personal lives (Haneline \& Aiex, 1997). Pirozzi (2003) best captures the significance of critical reading in regarding it as a necessity on the part of learners to uncover motivations and assess arguments, to consider options, products, advertisements and commercials, and to judge policies and programs offered by the various levels of government. It could help students analyze the written texts in terms of the author's main argument, sufficiency of the evidence provided to support this argument, tone and style employed by the author in the text and the overall credibility of the subject matter (Gulcat, 2014). To conclude, as Stamp (2012) asserts, 


\section{Zainab Hasan Muhammad}

critical reading makes reading more than an act of gazing over a page of words, but a way to enhance analytical skills and expand intelligence. Therefore, it is crucial for teachers of English to help their students become critical readers (Khodary \& AbdAllah, 2014).

\section{METHOD}

\subsection{RESEARCH DESIGN}

The current study employed a one-group pre-posttest quasiexperimental design. The participants were pre-tested, then received the MALL program, and finally post-tested.

\subsection{VARIABLES}

The study included an independent variable (the mobile-assisted language learning) as well as a dependent variable (critical reading). Operational definitions of both variables are listed below.

\subsubsection{MOBILE ASSISTED LANGUAGE LEARNING}

Mobile-assisted language learning was operationally defined by the researcher as a synchronous and asynchronous learning program, which includes the use of a number of mobile applications such as Google Classroom App and WhatsApp Messenger, for developing critical reading skills of EFL major students at Faculty of Education, Suez University.

\subsubsection{CRITICAL READING}

Critical reading was operationally defined by the researcher as an interactive process between the reader and the text in order to enhance the ability of determining the author's purpose of the text, anticipating his/her stated opinions and intended meanings, drawing inferences, differentiating between facts and opinions, recognizing bias, and evaluating the relevance of any sentence to the main topic.

\subsection{PARTICIPANTS}

Participants were 40 third-year EFL majors at the Faculty of Education, Suez University, during the second semester of 2017/2018 randomly chosen among a population of 82 students. Participants' ages ranged between 20 to 22 years. All participants spent at least 10 years 
learning EFL. All the participants have mobile phones and use educational and social apps.

\subsection{INSTRUMENT}

A pre-post critical reading skills test (CRST) was designed by the researcher to measure the EFL majors' critical reading skills. The test consisted of 19 MCQs covering the six previously-assigned critical reading skills in the adopted definition of critical reading. The test is divided into three sections. The first section consisted of 7 MCQs in the form of short passages/sentences. The second section included a comic with 6 MCQs. The third section contained 6 MCQs under two long passage. Eleven experts in the field of TEFL were relied on for their opinions on the appropriateness of the test items. The test was administered to 30 third-year EFL major students, out of the sample of the study. Piloting aimed to ensure the clarity of the instructions of the CRST and to determine the time needed for completing the test. The researcher achieved construct validity through calculating Pearson's Coefficient of correlation between the scores of 30 third-year EFL students on CRST. The coefficient of correlation between the critical reading skills and the total score of the test ranged between $(0.395$ and $0.607)$ and all the values are significant at the level of (0.01). Test-retest reliability was achieved through administering the test twice, with a 14day time span. Pearson's Coefficient of correlation between the two administrations was .573. The coefficient is significant at the 0.01 level.

\subsection{PROCEDURES}

The experimental procedures of the present study were carried out during the second semester of the 2017-2018 academic year in four successive stages: pretesting, setting the scene, implementing the mobileassisted language learning program (MALLP), and post-testing. As for pretesting and posttesting, the critical reading test was administered to all participants before and after implementing the mobile-assisted language learning program, respectively. The two remainder stages are described below.

\subsubsection{SETTING THE SCENE}

Before the administration of the program, the researcher presented an orientation session at the Faculty of Education, Suez University in order 
to introduce the program's aims, procedures, rules and apps. Participants were divided into small groups (five-member groups) and the researcher then assigned the roles of each member as the Timekeeper, the Questioner, the Reporter. Each small group were required to select a name and to install the required apps for the program such as (Adobe Acrobat Reader PDF app, Dictionary app, Google drive app, Google Classroom app, WhatsApp Messenger). The main app of the MALLP was Google Classroom. On the WhatsApp Messenger, the teacher created a group with each sub-group to follow up the program's sessions.

\subsubsection{IMPLEMENTING THE MALLP}

After the orientation session, participants were exposed to the MALLP twice a week during the second semester of the 2017-2018 academic year within the "Using Technology in Teaching EFL" course. Six asynchronous learning sessions on Google Classroom with three synchronous feedback sessions in between. The asynchronous sessions started with a warming activity to the assigned skill, which was either a video with caption, image, or a reading text posted on the Google Classroom App. After uploading the materials of the session from their folders on the app, students learned how this skill helps them become better critical readers. Later, the participants practiced some activities previously prepared by the researcher on the target skill by viewing them either through the Google Classroom app or sending links through WhatsApp messenger. In this stage, the students were independently practicing the target skill individually (Individual activities) and in small groups for cooperation competition (In-group activities). The teacher, in the following stage, assessed the learning outcomes and the acquisition of the skills taught to the students through sending different assessing tools such as checklists, home assignments, ...etc. to the participants' folders on the Google Classroom app with instant feedback.

\section{RESULT}

Paired-samples t-test was used to compare mean scores of the participants on the pretest and the posttest of critical reading skills. This dependent $\mathrm{t}$-test revealed a statistically significant difference $(\mathrm{t}=14.303$, $\mathrm{p}<0.05$ ), in favor of the posttest; see Table 3 . Additionally, the effect-size was found $(\mathrm{d}=4.58)$. This effect size is considered "large" according to Ellis (2010) who indicates that a large effect size corresponds to a range of 0.8 or more. 
MOBILE ASSISTED LANGUAGE LEARNING FOR DEVELOPING CRITICAL READING SKILLS OF EFL UNIVERSITY STUDENTS

Table 3: The means of the EFL critical reading test items

\begin{tabular}{|c|c|c|c|c|c|}
\hline Skills & \multicolumn{5}{|c|}{ Means of Test Items } \\
\hline \multirow{3}{*}{ Purpose } & Items & Q1 & Q12 & Q14 & Q17 \\
\hline & Pre & .90 & 1.10 & 1.30 & .05 \\
\hline & Post & .65 & .45 & 1.65 & 1.70 \\
\hline \multirow{3}{*}{$\begin{array}{l}\text { Intended } \\
\text { Meaning }\end{array}$} & Items & Q2 & Q5 & \multicolumn{2}{|c|}{ Q8 } \\
\hline & Pre & .05 & .00 & \multicolumn{2}{|c|}{.10} \\
\hline & Post & 1.85 & .10 & \multicolumn{2}{|c|}{1.55} \\
\hline \multirow{3}{*}{ Inference } & Items & Q6 & Q11 & \multicolumn{2}{|c|}{ Q19 } \\
\hline & Pre & 1.25 & .85 & \multicolumn{2}{|c|}{1.10} \\
\hline & Post & 1.65 & 1.20 & \multicolumn{2}{|c|}{1.20} \\
\hline \multirow{3}{*}{$\begin{array}{l}\text { Facts Vs. } \\
\text { Opinions }\end{array}$} & Items & Q7 & Q10 & \multicolumn{2}{|c|}{ Q15 } \\
\hline & Pre & .50 & 1.35 & \multicolumn{2}{|c|}{.65} \\
\hline & Post & .85 & 1.60 & \multicolumn{2}{|c|}{1.10} \\
\hline \multirow{3}{*}{ Bias } & Items & Q3 & Q13 & \multicolumn{2}{|c|}{ Q16 } \\
\hline & Pre & 1.50 & .30 & \multicolumn{2}{|c|}{1.80} \\
\hline & Post & 1.30 & .50 & \multicolumn{2}{|c|}{1.85} \\
\hline \multirow{3}{*}{ Evaluation } & Items & Q4 & Q9 & \multicolumn{2}{|c|}{ Q18 } \\
\hline & Pre & 1.20 & 1.10 & \multicolumn{2}{|c|}{.75} \\
\hline & Post & 1.55 & 1.60 & \multicolumn{2}{|c|}{.90} \\
\hline
\end{tabular}




\section{Zainab Hasan Muhammad}

Table 4: Results of Paired-samples t-test on the pre-post administration of the EFL critical reading test

\begin{tabular}{|c|c|c|c|c|c|}
\hline Skills & Measurement & $\mathbf{N}$ & Mean & SD & $\overline{\mathbf{T}}$ \\
\hline \multirow{2}{*}{ Purpose } & Pre & 40 & 3.35 & 1.889 & \multirow{2}{*}{2.959} \\
\hline & Post & 40 & 4.45 & 1.600 & \\
\hline \multirow{2}{*}{$\begin{array}{l}\text { Intended } \\
\text { Meaning }\end{array}$} & Pre & 40 & 3.05 & 1.431 & \multirow{2}{*}{3.873} \\
\hline & Post & 40 & 4.05 & 1.467 & \\
\hline \multirow{2}{*}{ Inference } & Pre & 40 & .15 & .533 & \multirow{2}{*}{20.154} \\
\hline & Post & 40 & 3.50 & .987 & \\
\hline \multirow{2}{*}{$\begin{array}{l}\text { Facts Vs. } \\
\text { Opinions }\end{array}$} & Pre & 40 & 2.50 & 1.617 & \multirow{2}{*}{3.280} \\
\hline & Post & 40 & 3.55 & 1.535 & \\
\hline \multirow{2}{*}{ Bias } & Pre & 40 & 3.60 & 1.297 & \multirow{2}{*}{.172} \\
\hline & Post & 40 & 3.65 & 1.494 & \\
\hline \multirow{2}{*}{ Evaluation } & Pre & 40 & 3.20 & 1.556 & \multirow{2}{*}{2.806} \\
\hline & Post & 40 & 4.05 & 1.154 & \\
\hline
\end{tabular}

Table 5: Paired-samples t-test of the difference between the means of scores of the participants on the pretest and the posttest of critical reading skills

\begin{tabular}{cccccc}
\hline & Mean & SD & T & df & $\begin{array}{c}\text { Sig. } \\
\text { (2-tailed) }\end{array}$ \\
\hline Pre & 16.30 & 3.67 & 14.303 & 39 & Significant at 0.05 \\
Post & 25.70 & 3.911 & & \\
\hline
\end{tabular}

\section{DISCUSSION}

The hypothesis of the current study stated that "There would be no statistically significant difference in the participants' mean scores between the pretest and the posttest of critical reading skills test." In order to test that hypothesis, the researcher used a dependent sample t-test to compare mean scores of both the pretest and the posttest of critical reading skills. This dependent $t$-test revealed a statistically significant difference $(\mathrm{t}=14.303, \mathrm{p}<0.05)$, in favor of the posttest. Additionally, a large effectsize was found $(\mathrm{d}=4.58)$. This result suggested that the participants have achieved significant improvements in their critical reading skills during the period of the experiment.

In light of this result, the hypothesis was completely rejected. This significant finding can be attributed to the nature of the instructional program based on mobile technology. The participants' skills and their prior knowledge and experience with mobile devices for learning play a crucial role in the output quality of such a mobile-based program and the 


\section{SKILLS OF EFL UNIVERSITY STUDENTS}

overall result. Therefore, introducing a learning program using mobile apps, such as Google Classroom, was not an obstacle for most of the students. Another possible explanation might have been that using smart phones applications increased students' motivation towards learning and developed their critical reading skills. As Weinstein, Husman, and Dierking (2000) confirm, the probability of success in any learning activity is largely determined by students' motivation and learning strategies. Such an explanation is supported by the findings of most of the previous studies such as those of Abu Laban (2017), Böhm and Constantine (2016), Çetin (2015), Chen, Chang, and Wang (2008), Chen, Liu, and Hwang (2016), Huang, et al. (2016), Mellati and Khademi (2015), Singaravelu (2009), Su and Cheng (2015), Vibulphol (2016), Yilmaz (2015). All of these studies confirmed that Mobile Learning in general and Mobile Learning Applications in particular have a positive impact on developing students' interest, motivation and achievement.

\section{CONCLUSION}

Based on the analysis of the study results and the discussion mentioned above, it can be concluded that using mobile assisted language learning (MALL) inside the Egyptian Faculties could have a high impact on developing EFL critical reading skills for major students. To sum up, applying mobile technology inside and outside college environments pave the way for EFL learners to become advanced critical readers.

\section{RECOMMENDATIONS AND SUGGESTIONS}

Based on the results and the conclusions drawn from this study, the researcher recommends: 1) incorporating mobile device use in the language-learning curriculum and using technology inside classrooms as a top priority by both teachers and students to improve all EFL skill, 2) allowing teachers and students to communicate with each other in mobile-assisted language learning environments, such as WhatsApp, for extra support, assistance, instant feedback, consultations, etc., which could be very instrumental to the language learning process in enhancing $\mathrm{t} / \mathrm{s}$ and s/s interaction, 3) holding workshops and more training sessions about new ways of teaching with technology between EFL instructors in schools and universities to benefit from technology in teaching English language skills, 4) emphasizing the importance of developing critical reading skills as one of the primary survival skills for the new millennium at Universities or other tertiary institutions. Furthermore, the following 


\section{Zainab Hasan Muhammad}

suggestions can be considered for further research: 1) MALL for developing EFL critical writing skills, 2) developing critical reading skills through MALL in EFL instructions for different samples such as (precollege EFL students, post-graduate students), 3) the effectiveness of MALL on EFL self-regulation, self-directed learning and self-efficacy, 4) a survey study on the EFL teachers' usages and perspectives of integrating MALL applications into language learning, 5) investigating the effectiveness of using new directions as (Massive Open Online Courses or MOOCs) on developing EFL skills. 


\section{REFERENCES}

[1] Abdel halim, S. M. (2011). Improving EFL majors' critical reading skills and political awareness: A proposed translation program. International Journal of Educational Research, 50(5-6), 336-348. Retrieved from https://www.sciencedirect.com/science/article/pii/S0883035511001078

[2] Abu Laban, Mousa, Mahmoud. (2017). The Effectiveness of Using Mobile Learning in Developing Eleventh Graders' English Grammar Learning and Motivation for English. Unpublished Dissertation, Gaza, Palestine.

[3] Abu Zeid, H. (2017). The Effect of Using a Blended E-Learning Program Based on Metacognition on Developing First Year Secondary School Students' Critical Reading and Critical Writing Skills. Ph. D. Dissertation. Faculty of Education, Minia University.

[4] AbuSa'aleek, A. O. (2014). A review of emerging technologies: Mobile assisted language learning (MALL). Asian Journal of Education and eLearning (ISSN: 2321-2454), 2(06). Retrieved from https://pdfs.semanticscholar.org/bf41/8cc63284e778f4a71892b086fe1e655f 8415.pdf

[5] Ahmad, S. (2012). The Effect of WebQuests on EFL Students' Critical Reading. study was presented at the $1^{\text {st }}$ International Conference of the Egyptian Association for Curriculum \& Instruction, Suez, Egypt, September $5-6$, 2012. Retrieved from https://www.academia.edu/13700334/The_Effect_of_WebQuests_on_EFL_ Students_Critical_Reading

[6] Akın, F., Koray, Ö., \& Tavukçu, K. (2015). How effective is critical reading in the understanding of scientific texts?. Procedia-social and behavioral sciences, 174, 2444-2451. Retrieved from https://www.sciencedirect.com/science/article/pii/S1877042815009672

[7] Albeckay, E. M. (2014). Developing Reading Skills through Critical Reading Programme amongst Undergraduate EFL Students in Libya. Procedia-Social and Behavioral Sciences, 123, 175-181. Retrieved from https://www.sciencedirect.com/science/article/pii/S1877042814014505

[8] Alemi, M., Sarab, M., \& Lari, Z. (2012). Successful learning of academic word list via MALL: Mobile Assisted Language Learning. International Education Studies, 5(6), 99-109. Retrieved from https://files.eric.ed.gov/fulltext/EJ1067052.pdf 
[9] Alqatanani, A. (2017). Do Multiple Intelligences Improve EFL Students' Critical Reading Skills?. Arab World English Journal (AWEJ) Volume, 8. Retrieved from https://papers.ssrn.com/sol3/papers.cfm?abstract_id=2945910

[10] Al-Sayed, R. (2010). The effectiveness of a suggested strategy for developing English language critical reading skills among experimental primary school pupils. M. Ed. Thesis. Faculty of Education, Benha University.

[11] Al-Zahrani, A. (2015). The Impact of Flipped Classroom on Cognitive Achievement in eLearning Course among Students from the Faculty of Education at King Abdulaziz University [Arabic]. The Journal of the Faculty of Education at the University of Al-Azhar, 162(1). Retrieved from https://www.researchgate.net/publication/285420355_The_Impact_of_Flipp ed_Classroom on Cognitive_Achievement in eLearning_Course among Students_from_the_Faculty_of_Education_at_King_Abdulaziz_University_ Arabic

[12] Arıc1, A.F.(2012); Reading Education, (3 ${ }^{\text {nd }}$ ed.), Pegem Akademi, Ankara.

[13] Aşılıoğlu, B. (2008). Importance and means of improving Critical Reading for Cognitive Learning. Journal of DU Ziya Gökalp", Faculty of Education, 10, 1-11.

[14] Badawy, M. (2018). Evaluating and Developing Critical Reading Skills Using an Interactive Digital Storytelling Environment for Third Year Preparatory Students. M. Ed. Thesis. Faculty of Education, Kafrelsheikh University, Egypt.

[15] Bahagat, M. (2015). The effect of using self-regulated learning strategies on developing English critical reading skills of first year experimental secondary school students. M. Ed. Thesis. Faculty of Education, Suez Canal University, Egypt.

[16] Barakat, M. (2018). The Effect of Using a Program Based on Some Critical Thinking Strategies on Developing Reading and Writing Skills of 1st Year English Majors at Minia University Faculty of Education. M. Ed. Thesis. Faculty of Education, Minia University.

[17] Bedeer, F. (2017). The effect of a brain-based learning program on developing primary stage students' English language critical reading skills. Ph. D. Dissertation. Faculty of Education, Ain Shams University.

[18] Bhullar, M.S. (2014). A new method of learning: M-Learning (Mobile Learning). $20149^{\text {th }}$ International Conference on Computer Science \& Education, 322-325. Retrieved from https://doi.org/10.1109/ICCSE.2014.6926478 
[19] Böhm, S., Böhm, S., Constantine, G. P., \& Constantine, G. (2016). Impact of contextuality on mobile learning acceptance: An empirical study based on a language learning app. Interactive Technology and Smart Education, 13(2), $107-\quad 122 . \quad$ Retrieved from https://www.emeraldinsight.com/doi/full/10.1108/ITSE-02-2016-0003

[20] Brantes Ferreira, J., Zanela Klein, A., Freitas, A., \& Schlemmer, E. (2013). Mobile learning: definition, uses and challenges. In Increasing student engagement and retention using mobile applications: Smartphones, Skype and texting technologies (pp. 47-82). Emerald Group Publishing Limited. Retrieved from http://dx.doi.org/10.1108/S20449968(2013)000006D005

[21] Burston, J. (2013). Mobile-assisted language learning: A selected annotated bibliography of implementation studies 1994-2012. Language Learning \& Technology, 17(3),157-224. Retrievable from http://1tt.msu.edu/issues/october2013/burston.pdf

[22] Carrigus, R. (2002). Design in reading: An introduction to critical reading. New York: Longman.

[23] Castro, J. M. (2019). Vulnerability to Fake News and Reading Comprehension of Grade 9 Students (Proposed Title). Ateneo De Manila University. https://www.academia.edu/39575753/Vulnerability to_Fake_News_and_R eading_Comprehension_of_Grade_9_Students_Proposed_Title_

[24] Cetin, B. (2015). Predicting academic success from academic motivation and learning approaches in classroom teaching students. Contemporary Issues in Education Research (Online), 8(3), 171. Retrieved from https://files.eric.ed.gov/fulltext/EJ1069894.pdf

[25] Chen, C. \& Chung, C. (2008). Personalized mobile English Vocabulary Learning System Based On Item Response Theory and Learning Memory Cycle. Computers \& Education, 51(2), 624-645. Retrieved from http://dx.doi.org/10.1016/j.compedu.2007.06.011

[26] Chen, C., Liu, G., \& Hwang, G. (2016). Interaction between gaming and multistage guiding strategies on students' field trip mobile learning performance and motivation. British Journal of Educational Technology. 47(6) 1032-1050. Retrieved from https://doi.org/10.1111/bjet.12270

[27] Chen, G., Chang, C., \& Wang, C. (2008). Ubiquitous learning website: Scaffold learners by mobile devices with information-aware techniques. Computers \& Education, 50(1), 77-90. Retrieved from https://doi.org/10.1016/j.compedu.2006.03.004 


\section{Zainab Hasan Muhammad}

[28] Collins, H. (2018). Creative research: the theory and practice of research for the creative industries. ( $2^{\text {nd }}$ ed.). Bloomsbury Publishing. Retrieved from https://books.google.com/books?hl=ar\&lr=\&id=DdhwDwAAQBAJ\&oi=fn $\mathrm{d} \& \mathrm{pg}=\mathrm{PR} 3 \& \mathrm{dq}=\% 22 \mathrm{Creative}+$ research + The + theory $+\% 26+$ practice + of + re search+for+the+creative+industries \%22\&ots=YWnJf5UXW1\&sig=41QuB3 gZPfVkRA2pC09j75nDzD8

[29] Cusipag, M. N., Aglaua, C. M., Balarbar, C. V., Madrunio, M. R., Miciano, R. Z., \& Mojica, L. A. (2006). Critical thinking through reading and writing. Manila: De La Salle University Press. OpenURL.

[30] diSessa, A. $(Y \cdots)$. Changing minds: Computers, learning \& literacy. Cambridge: MIT Press.

[31] Duncan, B. (2006). Media Literacy: Essential Survival Skills for the New Millennium. School Libraries in Canada (17108535), 25(4), 31-34. Retrieved from http://search.ebscohost.com/login.aspx?direct=true \&db=a9h\&AN=2398761 2\&site $=$ ehost-live

[32] Ellis, P. (2010). The Essential Guide to Effect Sizes: Statistical Power, Meta-Analysis, and the Interpretation of Research Results. Cambridge University Press. Retrieved from https://doi.org/10.1017/CBO9780511761676

[33] Ellozy, A. \& Mostafa, H. (2010). Making learning visible: Using e-maps to enhance critical reading skills. MERLOT Journal of Online Learning \& Teaching, 6(3), 634-646. Retrieved from http://jolt.merlot.org/vol6no3/ellozy 0910.pdf

[34] El-Maleh, A. (2006). A proposed literature circles program for teaching short story to secondary school students \& its effect on their critical reading. Ph. D. Dissertation, El-Arish Faculty of Education, Suez Canal University.

[35] El-Mistikawy, W. (2016). The effect of critical reading (CR) on developing 1st year preparatory students' creative English writing (CW) skills. M. Ed. Thesis. Faculty of Education, Ain Shams University.

[36] El-Sakka, S. (2011). A proposed program based on blending the process writing with web logs to develop the writing performance \& critical reading of EFL prospective teachers. Ph. D. Dissertation. Suez Faculty of Education, Suez Canal University.

[37] Garcia, J. C. (2002). Tele-enREDando. com: A multimedia WEB-CALL software for mobile phones. IJES, International Journal of English Studies, 2(1), 167-178. Retrieved from https://dialnet.unirioja.es/descarga/articulo/272490.pdf 
[38] Geddes, S. J. (2004). Mobile learning in the 21st century: benefit for learners. Knowledge Tree e-journal of Flexible Learning in VET, vol.6. Retrieved from http://pandora.nla.gov.au/pan/33606/200509280000/www.flexiblelearning.net.au/knowledgetree/edition06/html/pra simon geddes.html

[39] Gharib, M. (2012). Using inference skills to develop some critical reading skills of EFL prospective teachers. M. Ed. Thesis. Faculty of Education, Suez Canal University, Egypt.

[40] Gromik, N. (2012). Cell Phone Video Recording Feature as A Language Learning Tool: A Case Study. Computers \& Education, 58(1), 223-230. Retrieved from https://doi.org/10.1016/j.compedu.2011.06.013

[41] Gulcat, Z. (2004). Critical reading towards critical writing. Retrieved from http://www.utoronto.ca/writing/critrdge.html

[42] Haneline, D. \& Aiex, N. (1997). Asking the right questions: Reading assignments that work for writing. ERIC Clearinghouse on Reading, English، and Communication Digest\#122. Retrieved from http://www.indiana.edu/reading/ieo/digests/d122.html

[43] Huang, C., Yang, S., Chiang, T., \& Su, A. (2016). Effects of Situated Mobile Learning Approach on Learning Motivation and Performance of EFL Students. Educational Technology \& Society, 19(1), 263-276. Retrieved from https://www.jstor.org/stable/pdf/jeductechsoci.19.1.263.pdf?seq=1\#page_sc an tab contents

[44] Karabay, A., Kuşdemir Kayıran, B., \& Işık, D. (2015). The investigation of pre-service teachers' perceptions about critical reading self-efficacy. Eurasian Journal of Educational Research, 59, 227-246. Retrieved from http://dx.doi.org/10.14689/ejer.2015.59.12

[45] Kharbach, M. (2018, August 22). 13 Questions to Help Students Develop Critical Reading Skills [Blog post]. Retrieved from https://www.educatorstechnology.com/2018/01/critical-reading-checklist12-questions.html

[46] Khodary, M. M., \& AbdAllah, M. M. (2014). Using a WebQuest Model to Develop Critical Reading Achievement among Languages and Translation Department Students at Arar College of Education and Arts. International Interdisciplinary Journal of Education, 1(1522), 1-11. Retrieved from https://platform.almanhal.com/Files/Articles/55362 


\section{Zainab Hasan Muhammad}

[47] Kiernan, P., \& Aizawa, K. (2004). Cell phones in task based learning: Are cell phones useful language learning tools? ReCALL, 16(1), 71-84. Retrieved from https://doi.org/10.1017/S0958344004000618

[48] Kukulska-Hulme, A. (2005). The Mobile Language Learner-Now and in The Future. Fran Vision till Praktik. Language Learning Symposium conducted at Umea University in Sweden. http://www2.humlab.umu.se/symposium2005/program.htm.

[49] Kurland, D. (2002). How the language really works: The fundamentals of critical reading and effective writing-critical reading v. critical thinking. Retrieved

from http://www.criticalreading.com/critical_reading_thinking.htm

[50] Leu, D. \& Kinzer, C. (2000). The convergence of literacy instruction with networked technologies for information \& communication. Reading Research Quarterly, 35، 108-127. Retrieved from https://ila.onlinelibrary.wiley.com/doi/abs/10.1598/RRQ.35.1.8

[51] Levy, M., \& Kennedy, C. (2005). Learning Italian via mobile SMS. In A. Kukulska- Hulme \& J. Traxler (Eds.), Mobile learning: A Handbook for Educators And Trainers, London: Routledge. pp. 76-83.

[52] Makhyoun, W. (2008). The effectiveness of story mapping journal writing strategy in developing some critical reading skills among prospective teachers at the faculty of education. M. Ed. Thesis. Damanhour Faculty of Education, Alexandria University.

[53] McClain, A. (1985). Using traditional literature to teach critical reading skills. Paper presented at the Annual Meeting of the Far West Regional Conference of the International Reading Association (15, Portland OR, March 7-9, 1985). Retrieved from https://eric.ed.gov/?id=ED260381

[54] McDonald, L. (2004). Moving from reader response to critical reading: Developing 10-11 year olds ability as analytical readers of literary texts. Literacy, $38 \quad$ (1), 17-25. Retrieved from https://onlinelibrary.wiley.com/doi/abs/10.1111/j.0034$\underline{0472.2004 .03801004 . x}$

[55] Mekhzoumi, O., Hilmi bin Hamzah, M., \& N. Krishnasamy, H. (2018). Investigating Acceptance of Mobile Applications Toward English Language Learning: Based On Qualitative Judgments. Asian Journal of Multidisciplinary Studies, 6(10). Retrieved from http://www.ajms.co.in/sites/ajms2015/index.php/ajms/article/view/3264

[56] Mellati, M., \& Khademi, M. (2015). The Impacts of Distance Interactivity on Learners' Achievements in Online Mobile Language Learning: Social Software and Participatory Learning. International Journal of Web-Based 
Learning and Teaching Technologies (IJWLTT), 10(3), 19-35. Retrieved from

https://www.researchgate.net/publication/276500336_The_Impacts_of_Dist ance Interactivity on_Learners'_Achievements in Online_Mobile_Langua ge Learning

[57] Nitsu, N. (2004). Critical thinking skills \& Japanese as a second language reading textbooks. M. Ed. Thesis, Faculty of Education, Lethbridge, Alberta. Retrieved from http://opus.uleth.ca/handle/10133/1063

[58] O’Malley, C., Vavoula, G., Glew, J.P., Taylor, J., Sharples, M., Lefrere, P., Lonsdale, P., Naismith. L., \& Waycott, J. (2005). Guidelines for learning/teaching/tutoring in a mobile environment. Retrieved from https://hal.archives-ouvertes.fr/hal-0069624

[59] Pilar, R. A., Jorge, A., \& Cristina, C. (2013). The use of current mobile learning applications in EFL. Procedia-Social and Behavioral Sciences, 103, 1189-1196. Retrieved from https://doi.org/10.1016/j.sbspro.2013.10.446.

[60] Pirozzi, R. (2003). Critical reading, critical thinking ( $2^{\text {nd }}$ ed.). New York. Longman.

[61] Prensky, M. (2001). Digital natives, digital immigrants part 1. On the horizon, $9(5)$ https://www.emeraldinsight.com/doi/pdfplus/10.1108/10748120110424816

[62] Ragab, F. (2005). Developing some critical reading skills in English language in the secondary stage via the World Wide Web. M. Ed. Thesis. Faculty of Education, Mansoura University, Egypt.

[63] Rivers, D. (2009). Utilizing the Quick Response (QR) Code Within a Japanese EFL Environment. The JALT CALL Journal, 5(2), 15-28. Retrieved from https://journal.jaltcall.org/articles/5 2 2 Rivers.pdf

[64] Rivers, W. P. (2001). "Autonomy at All Costs: An Ethnography of Metacognitive Self-Assessment and Self-Management among Experienced Language Learners." The Modern Language Journal 85(2): 279-290. Retrieved from https://onlinelibrary.wiley.com/doi/abs/10.1111/0026$\underline{7902.00109}$

[65] Roe, B. \& Smith, S.(Y.11) . Teaching reading in today's elementary schools $\left(11^{\text {th }}\right.$ ed.) Belmont: Wadsworth Cengage Learning.

[66] Rog, L. J. (2012). Guiding readers: making the most of the 18-minute guided reading lesson. Pembroke Publishers Limited. Retrieved from https://books.google.com/books?hl=ar\&lr=\&id=WYZIAQAAQBAJ\&oi=fn $\mathrm{d} \& \mathrm{pg}=\mathrm{PP} 1 \& \mathrm{dq}=\% 22 \mathrm{Making}+$ the + most + of + the +18 -minute+guided- 


\section{Zainab Hasan Muhammad}

reading+Lesson\%22\&ots=KvpA3uamJs\&sig=YkCvvqGo9Qa1bJ1ZonJNcZ $\underline{\mathrm{bt} 0 \mathrm{aY}}$

[67] Sandberg, J., Maris, M., \& de Geus, K. (2011). Mobile English learning: An evidence-based study with fifth graders. Computers \& Education, 57(1), 1334-1347. Retrieved from https://doi.org/10.1016/j.compedu.2011.01.015

[68] Singaravelu, G. (2009). Mobile Learning to Enrich Vocabulary in English. i-Manager's Journal of Educational Technology, 6(2), 63-68.

[69] Stamp, K. $(Y \cdot I Y)$. The Importance of Critical Reading. Retrieved from http://www.helium.com/items/2242452-the-importance-of-critical-reading

[70] Su, C. H., \& Cheng, C. H. (2015). A mobile gamification learning system for improving the learning motivation and achievements. Journal of Computer Assisted Learning, 31(3), 268-286. Retrieved from https://onlinelibrary.wiley.com/doi/pdf/10.1111/jcal.12088

[71] Thistlethwaite, L. (1990). Critical reading for at-risk students. Journal of Reading, 33(8), 586-593. Retrieved from https://www.jstor.org/stable/40030513

[72] Thornton, P. \& Houser, C. (2005). Using mobile phones in English education in Japan. Journal of Computer Assisted Learning, 21: 217-228. doi:10.1111/j.1365-2729.2005.00129.x

[73] Trinder, J. (2005). Mobile Technologies and Systems. In A. \&. KuklskaHulme (Ed.), Mobile learning: A handbook for educators and trainers, USA: Taylor \& Francis.

[74] Twarog, M. \& Pereszlényi-Pintér, M. (1988). Telephone-Assisted Language Study and Ohio University: A report. The Modern Language Journal, 72, 426-434. Retrieved from https://doi.org/10.1111/j.15404781.1988.tb04204.x

[75] UNESCO (2013). UNESCO policy guidelines for mobile learning. Retrieved from: https://unesdoc.unesco.org/ark:/48223/pf0000219641

[76] Valarmathi, K. (2011). Mobile Assisted Language Learning. Journal of $\begin{array}{lll}\text { Technology for } & \text { ELT. } & 1(2) \text {. }\end{array}$ https://sites.google.com/site/journaloftechnologyforelt/archive/april2011/m obileassistedlanguagelearning

[77] Varga, R. (2011). The importance of enhancing critical thinking skill of pre-service teachers. Képzés és Gyakorlat/Training and Practice, 9(1-2), 97. Retrieved from https://pdfs.semanticscholar.org/84dd/954b29287bf4a8a91b31794a223f619 dc26b.pdf

[78] Vibulphol, J. (2016). Students' Motivation and Learning and Teachers' Motivational Strategies in English Classrooms in Thailand. English 
MOBILE ASSISTED LANGUAGE LEARNING FOR DEVELOPING CRITICAL READING SKILLS OF EFL UNIVERSITY STUDENTS

$\begin{array}{lllll}\text { Language } & \text { Teaching, } & \text { 9(4), } & \text { 64-75. } & \text { Retrieved from }\end{array}$ http://dx.doi.org/10.5539/elt.v9n4p64

[79] Weinstein, C., Husman, J., \& Dierking, D. (2000). Self-regulation interventions with a focus on learning strategies. In Handbook of selfregulation. Academic Press, 727-747. Retrieved from https://doi.org/10.1016/B978-012109890-2/50051-2

[80] Wolters, C. A., Pintrich, P. R., \& Karabenick, S. A. (2005). Assessing academic self-regulated learning. In What do children need to flourish? (pp. 251-270). Springer, Boston, MA. Retrieved from https://link.springer.com/content/pdf/10.1007/0-387-23823-9_16.pdf

[81] Wray, A. \& Wallace, M.(Y.11) Critical reading \& writing for postgraduates $\left(2^{\text {nd }} e d.\right)$. London: Sage.

[82] Yilmaz, Ö., \& Sanalan, V. (2015). Establishing a Multidimensional Interaction in Science Instruction: Usage of Mobile Technology. TOJET: The Turkish Online Journal of Educational Technology, 14(4), 38-52. Retrieved from http://www.tojet.net/articles/v14i4/1444.pdf 